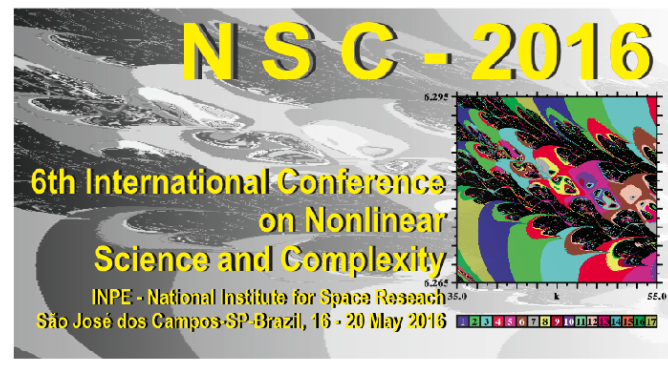

INPE - National Institute for Space Research

São José dos Campos - SP - Brazil - May 16-20, 2016

\title{
COMPLEX NETWORK INTO GEOGRAPHICAL INFORMATION SYSTEMS
}

\author{
Beatriz Marques Moreira da Silva ${ }^{1,2}$, Lucas O. Valerio $^{3,4}$, Maria C. B. Jurema ${ }^{3,4}$, Leonardo B. L. Santos ${ }^{5}$
}

\begin{abstract}
${ }^{1}$ Faculdade de Tecnologia Prof. Jessen Vidal (FATEC), São José dos Campos, Brasil, beatriz.mm.silva@gmail.com
${ }^{2}$ Bolsista de Iniciação Científica, FAPESP, pelo Centro Nacional de Monitoramento e Alertas de Desastres Naturais (Cemaden/MCTI), São José dos Campos, Brasil

${ }^{3}$ Universidade Estadual Paulista Júlio de Mesquita Filho (UNESP), São José dos Campos, Brasil, lucasvalerio@live.com, mariacarolinabj@gmail.com

${ }^{4}$ Bolsista de Iniciação Científica, CNPq, pelo Instituto Nacional de Pesquisas Espaciais (INPE), São José dos Campos, Brasil

${ }^{5}$ Centro Nacional de Monitoramento e Alertas de Desastres Naturais (Cemaden/MCTI), São José dos Campos/SP, Brasil, santoslbl@gmail.com
\end{abstract}

\begin{abstract}
Geographic Information Systems allow geographic data visualization and handling of geographical data, as traffic zone vectors (polygons adopted as a unit of urban mobility study) and hydrography (set of water courses in a region). The data structure representation of complex networks (set of nodes and edges representing a complex system) can be made considering, for example, the traffic zone centroids as the nodes, connected each other in accord of people flow, and river's headwater and outlet as the nodes and water courses as edges. The current work shows a computational schema to a complex network representation in a Geographic Information System.
\end{abstract}

keywords: Complex Networks, Geographic Information Systems, Urban mobility, Hydrography

\section{INTRODUCTION}

Networks, structures with nodes connected by edges, can represent several types of data, from Urban Mobility to Hydrography, some of them with complex behaviors.

Urban mobility studies focus on population's commute within an urban area, including, for example, how population groups move across the area and events that may disturb normal circulation, such as natural disasters - as floods in some watercourses [1].

Geographic Information Systems (GIS) allow geographic data visualization and handling of geographical data, as traffic zone vectors (polygons adopted as a unit of urban mobility study) and hydrography (set of watercourses in a region) [2].
This work shows a computational example to a complex network representation in a Geographic Information System, exploring the geographical location of the nodes [3].

\section{MATERIAL AND METHOD}

According [1], mobility data networks can be gathered by different means, por example, origindestination surveys (OD), which are expensive and demand professional efforts but draw a consistent scenario for typical daily movements of population groups. Each element $(i, j)$ in the OD matrix represents the number of people that do, in a common day, the travel between $\mathrm{i}$ (origin) and $\mathrm{j}$ (destination).

In this paper the OD data was from São José dos Campos [4], a municipality in the eastern region of São Paulo state, in the southeastern region of Brazil. Its population summed 629,921 inhabitants in 2010 in a land area of $1,099.6 \mathrm{~km} 2$. In this city there are 54 traffic zones.

The Geographical Information System QuantumGIS was used to data visualization.

\section{RESULTS AND PERSPECTIVES}

Figure 1 shows a network visualization in GIS. There are two shapefiles, the first one - a point-type shapefile related to the nodes (Traffic Zones's centroides), and the second one - a line-type shapefile, related to the edges. In this urban mobility network two nodes are connected if, and only if, there are at least one travel (in the mobility dataset) between these nodes. 


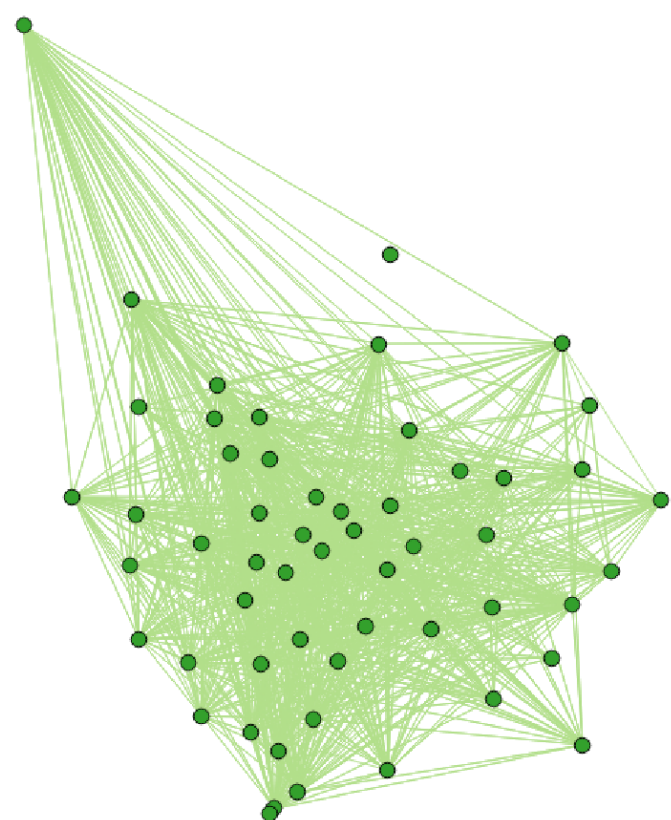

Figure 1 - Complex network of urban mobility - each node represents a (centroide of a) Traffic Zone, and the edges are related to the flow (OD data) between each pair of nodes.

This view shows the topological relationship between the centroids of mobility's spatial units and the people flow.

This is the first phase of a work that will include the results of graph's topological properties in its own display, then will be possible to visualize properties such as vulnerability as a visual property (color, shape, size) of both nodes and edges.

\section{ACKNOWLEDGMENTS}

We thank IPPLAN for the OD data, Aurelienne A. Souza Jorge for the useful help with geographical database management systems, $\mathrm{CNPq}$ - project $\mathrm{n}$. 454267/2014-2, and thank the research group "AmbientEMobilidade".

\section{References}

[1] LONDE, L. R.; SANTOS, L. B. L.; SORIANO, E.; TOMAS, L. R.; CARVALHO, T. (2015) Urban mobility data to support the assesment of dynamic vulnerability to disasters. In: II International Conference on Information and Communication Technologies for Disaster Management (ICT-DM), Paris.

[2] SANTOS, L. B. L.; LONDE, L. R.; SORIANO, E.; SOUZA, A.; COELHO, A. F. (2015) Potential floodrelated daily urban mobility problems in Rio de Janeiro (Brazil). Revista do Departamento de Geografia, v. 29, p. 175-190.

[3] SANTOS, L. B. L.; MACAU, E. E., IANNELLI, F.; SILVA, B. M. N.; CARVALHO, L. M.; COELHO, F. C.; MONTEIRO, A. M. V. (2016) Exploring the spatial structure of Rio de Janeiro's intra-urban mobility complex network. To be submitted.

[4] Instituto de Pesquisa, Administração e Planejamento IPPLAN (2014) (coord.) Atlas da pesquisa origem e destino - panorama da mobilidade em São José dos Campos - São Carlos : Editora Cubo, 144 p. 